\title{
23. STRATIFICATION IN MISSISSIPPI FAN CORES REVEALED BY X-RAY RADIOGRAPHY ${ }^{1}$
}

\author{
James M. Coleman, Louisiana State University \\ A. H. Bouma, Gulf Research and Development Company \\ H. H. Roberts, Louisiana State University \\ and \\ P. Thayer, Amoco Production Company²
}

\begin{abstract}
One hundred and eight thin sediment slabs were collected from Leg 96 Mississippi Fan cores for evaluation by X-ray radiographic techniques. Sedimentary structures and other textural features revealed by the radiographs, when combined with the overall vertical sequences, help characterize the various depositional environments and processes of deposition of the deep-sea fan sediments. Normally graded parallel laminae, ranging in thickness from less than $1 \mathrm{~mm}$ to several centimeters, are the most common small-scale sedimentary structure. These thin beds grade from either sand or silt to very fine clay; concentrations of foraminifers at the top of the fine clays are common. Microcross-stratification, thin distorted layers, and microfracturing are rather common; reworked plant material, mica, and volcanic shards are abundant. Diagenetic inclusions, while present, are not especially common, and bioturbation is extremely rare.
\end{abstract}

\section{INTRODUCTION}

Nine sites on the Mississippi Fan were visited during Deep Sea Drilling Project (DSDP) Leg 96 (Introduction and Explanatory Notes, this volume). Sediment slabs (6-mm thick, $7.5-\mathrm{cm}$ wide, and $30-\mathrm{cm}$ long) were sampled on board, sealed in Plexiglas frames, and transported to a shore-based laboratory for analysis by X-ray radiography. A Norelco commercial X-ray unit was used, and settings for the exposures were usually $28 \mathrm{kV}$ and $20 \mathrm{~mA}$. The source-to-slab distance was $56 \mathrm{~cm}$; general exposure times ranged from 8 to $10 \mathrm{~min}$., depending on the lithology of the sediment slab.

The DSDP Mississippi Fan drill sites are divided into five depositional groups on the basis of environments of deposition: middle fan channel (Sites 621 and 622), middle fan overbank (Sites 617 and 620), slump-marginal fan lobe (Site 616), lower fan channel-overbank (Sites 623 and 624), and lower fan channel-mouth sheet sands (Sites 615 and 614). (For locations of the sites, see introductory chapter, this volume.) Structural and textural features of the sediments from each of these depositional environments, as evidenced by slab X-ray radiography results, are discussed in this chapter.

\section{MIDDLE-FAN CHANNEL DEPOSITS}

Middle-fan channel Sites 621 and 622 show a finingupward channel-fill sequence starting with a basal lag gravel composed of quartzitic sandstones, faceted chert, and polycrystalline quartz up to $3 \mathrm{~cm}$ in diameter. The basal lag grades upward into quartz-rich sands containing chert granules, mica, and woody organic fragments. The

\footnotetext{
${ }^{1}$ Bouma, A. H., Coleman, J. M., Meyer, A. W., et al., Init. Repts. DSDP, 96: Washington (U.S. Govt. Printing Office).

2 Addresses: (Coleman, Roberts) Coastal Studies Institute, Louisiana State University, Baton Rouge, LA 70803; (Bouma, present address) Chevron Oil Field Research Company, P.O. Box 36506, Houston, TX 77236; (Thayer, present address) Mobil Oil Exploration and Producing Southeast Inc., 1250 Poydras Bldg., New Orleans, LA 70113
}

entire unit is capped by fine-grained silts and clays (passive channel fill) containing minor amounts of methane gas. Microfauna are rare in general, but reworked shallow-water benthic species were found in both the sands and the clays of the channel fill. Most of the thicker sands contain little evidence of any sedimentary structures, possibly because of liquefaction induced by coring operations.

In the upper finer grained "passive" channel fill, thick, poorly defined graded laminae (a in Fig. 1A), consisting of very fine silt at the base and grading upward into silty clay and clay, are present. Abundant small diagenetic inclusions (b in Fig. 1A), consisting of partially calciumcarbonate-cemented silt nodules, are scattered throughout the cores. In some instances, the inclusions occur in repetitive thin zones within both the fine silts and the clays (c in Fig. 2A). Microfractures (d in Fig. 1A) are common and probably result from differential compaction. In the finer grained clays, stratification is highly disturbed by biogenic methane gas escape structures (Fig. 1B). This disruption occurs because of degassing resulting from the lowering of the pressure as the cores are brought to the surface. The poorly defined layering and the presence of scattered planktonic microfauna tend to indicate that some of the sediment in the "passive" channel fill is hemipelagic.

In the central part of the channel fill, thin, fine sand and silt partings are more abundant (Fig. 1C). Normally graded beds, ranging in thickness from a few millimeters to several centimeters (a in Fig. 1C), are common. Sparse microfauna and scattered shallow-water benthic fauna indicate deposition by fine-grained density flows. Within this part of the channel-fill sequence, very thin (1 to $2 \mathrm{~mm}$ ) normally graded parallel laminations are often present (b in Fig. 1C). In most instances, calciumcarbonate-cemented inclusions (c in Fig. 1C) are present in the slightly coarser laminations. Near the base of the finer grained "passive" fill, thin cross-laminated sand 


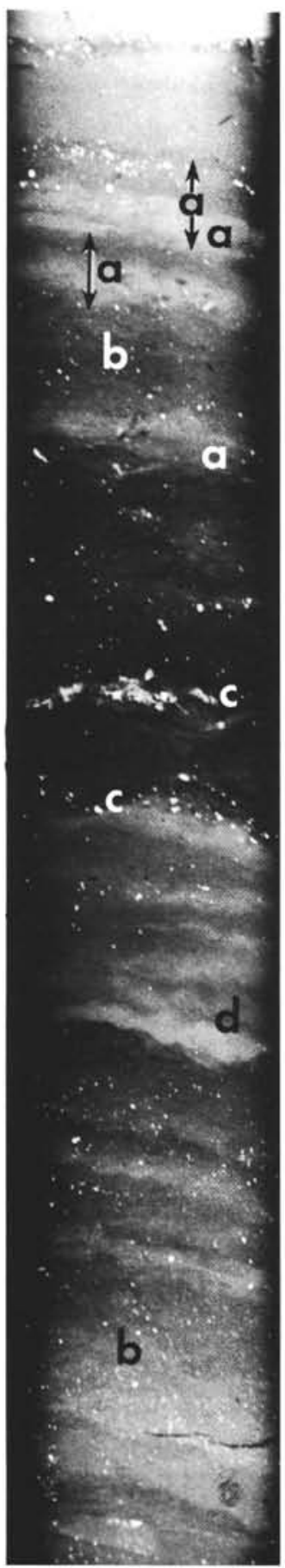

A

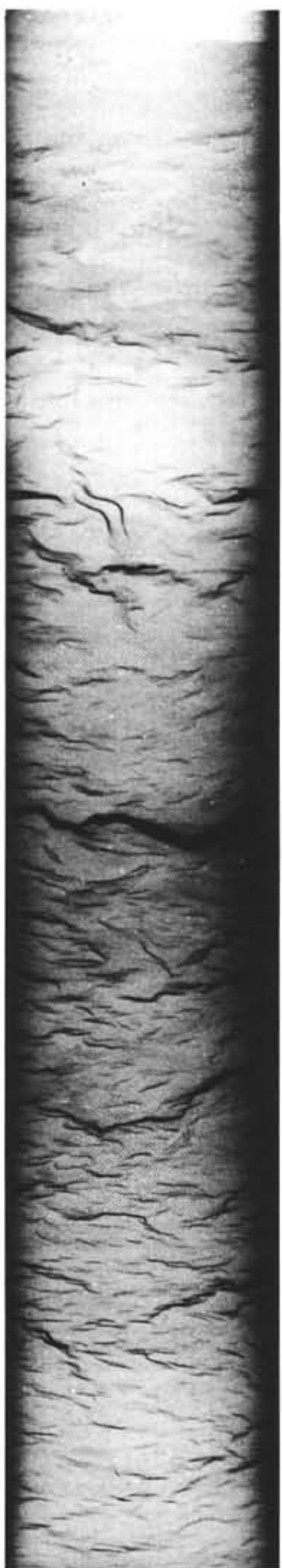

B

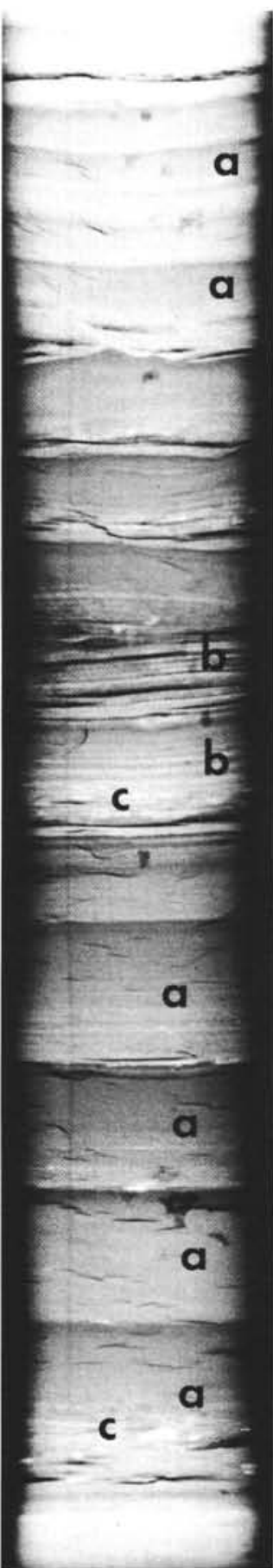

C

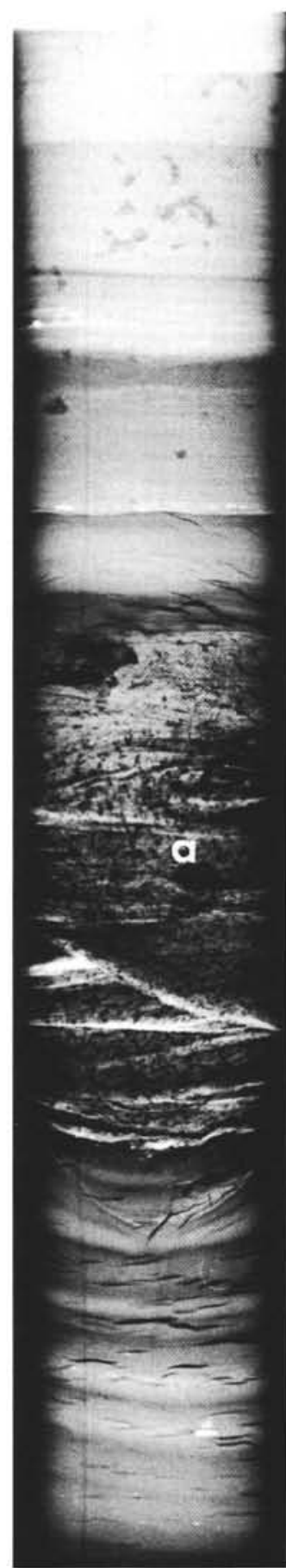

D

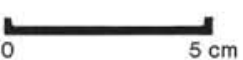

Figure 1. Radiographs of Mississippi Fan cores. A. Sample 622-2-3, 96-126 cm; channel fill. B. Sample 621-14-5, 96-126 cm; channel fill. C. Sample 622-10-4, 11-41 cm; channel fill. D. Sample $622-10-4,60-90 \mathrm{~cm}$; channel fill.

beds (a in Fig. 1D) are present. The sands contain scattered woody organic debris and mica. The sands display sharp bases, often scoured, and grade upward into silts and finally into clays. These units vary in thickness from 10 to $40 \mathrm{~cm}$.

The coarser grained basal channel sediments consist primarily of alternating sand and silt separated by thin clay layers (Fig. 2A-D). Normally graded beds, ranging from 10 to $50 \mathrm{~cm}$ in thickness, are extremely common (a in Fig. 2A). These graded units display sharp basal surfaces without any significant amount of scour; they grade upward to silty clays. The sands show small-scale crosslaminations (b in Fig. 2A) containing scattered woody debris and mica and grade upward into parallel or microcross-laminated silts (c in Fig. 2A), which in turn grade upward into finely laminated silty clays (d in Fig. 2A). 


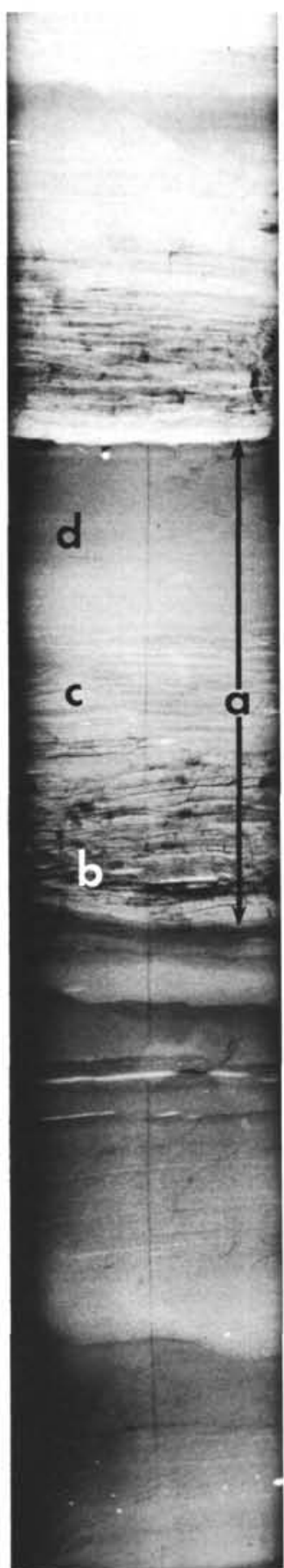

A

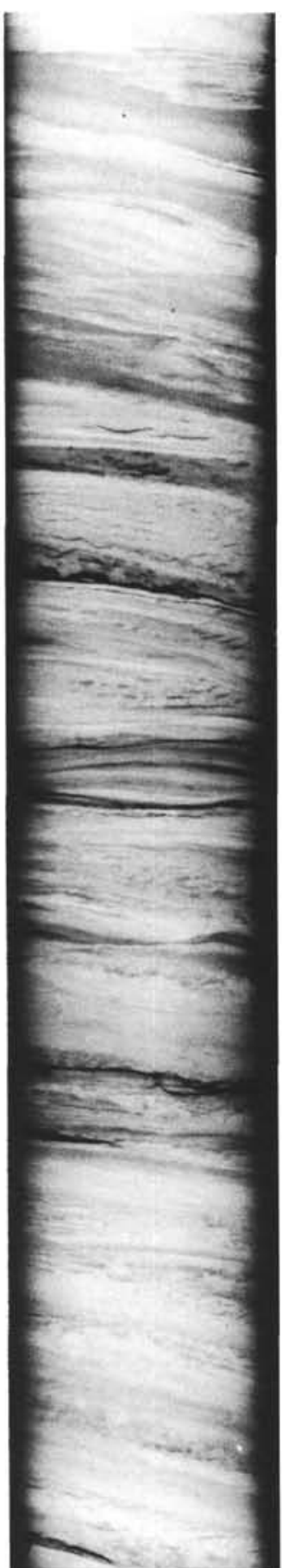

B

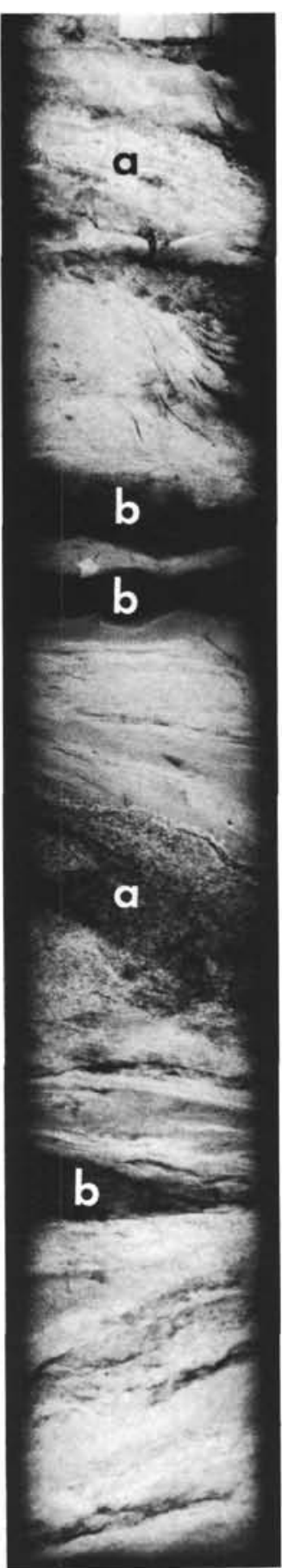

C

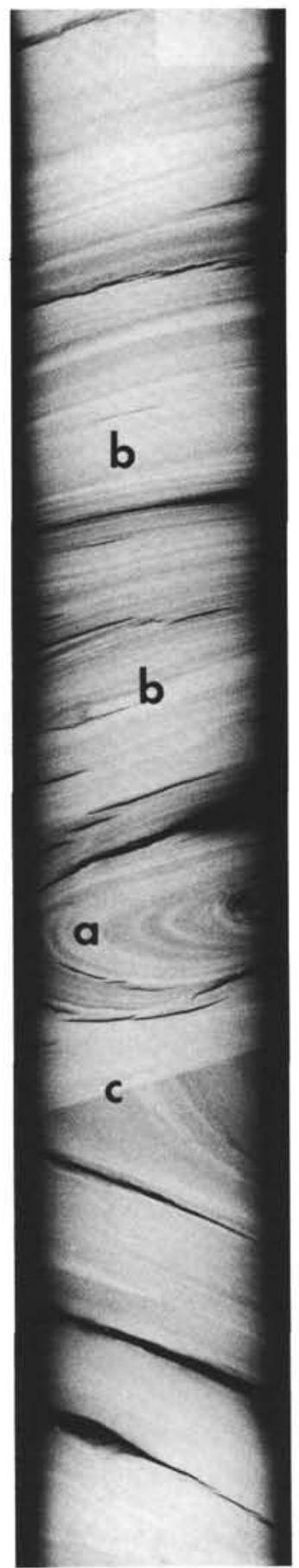

D

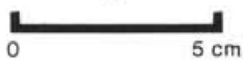

Figure 2. Radiographs of Mississippi Fan cores. A. Sample 622-11-3, 95-125 cm; channel fill. B. Sample 622-16-2, 111-141 cm; channel fill. C. Sample 621-26-1, 31-61 cm; channel fill. D. Sample 621-32-1, 46-76 cm; channel fill.

Multidirectional tilted beds, possibly indicating larger scale cross-bedding, are often present (Fig. 2B, 2C). The coarser sands ( $\mathrm{a}$ in Fig. 2C) tend to show little internal structure, but generally contain abundant scattered woody debris commonly referred to as "coffee grounds." Thin, very fine, low-absorption clay layers (b in Fig. 2C) often separate the sand layers. Small-scale distorted layers (a in Fig. 2D) are present, especially in the lower part of the basal channel deposits. The finer grained silts normally consist of very thin, parallel, graded laminations (b in Fig. 2D). Sharp, angular scour planes (c in Fig. 2D) are present, but not common.

\section{MIDDLE FAN OVERBANK DEPOSITS}

The overbank sites (617 and 620) are composed primarily of fine-grained sediments, with only minor 
amounts of sand. Bedding is generally thin, microfauna are rare but more abundant than in the channel, and the sediments can best be described as thin-bedded turbidites. One of the most common sedimentary structures is variable-thickness graded bedding (Fig. 3A). These parallel laminations (a in Fig. 3A) range in thickness from a few millimeters to over $10 \mathrm{~cm}$. They are generally

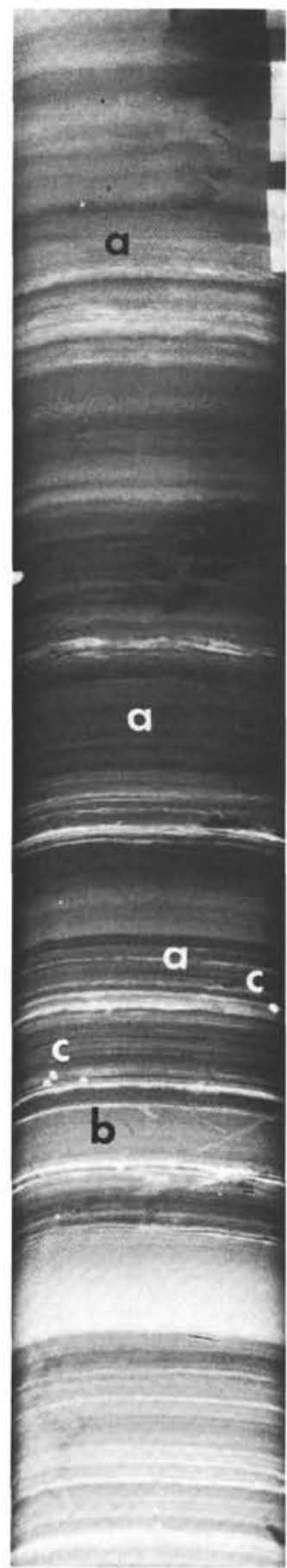

A

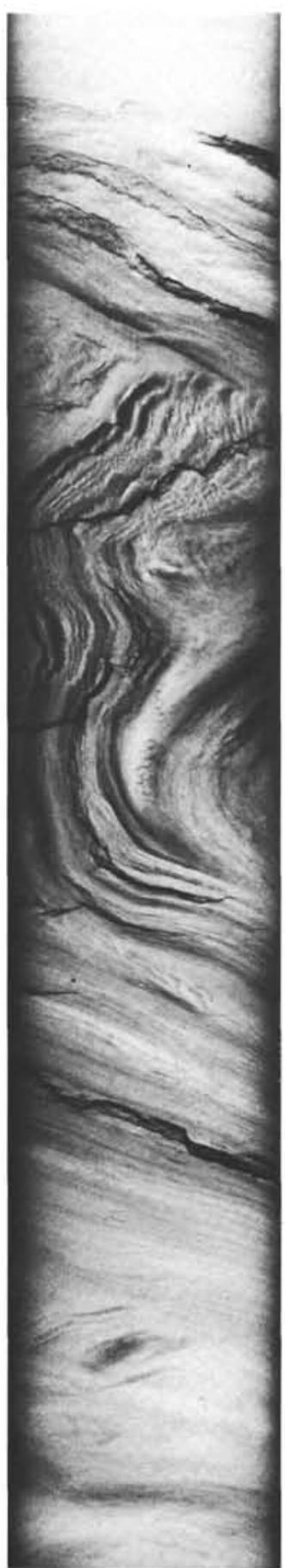

B characterized by a sharp basal contact of fine sand or silt, grading to a thinly laminated clay and capped by a homogeneous clay that often contains scattered microfauna and microburrows (b in Fig. 3A; a in Fig. 5A). In some instances, the basal sands display extremely thin parallel laminations that are themselves graded $(\mathrm{b}$ in Fig. 5A). A few small, diagenetically formed inclusions

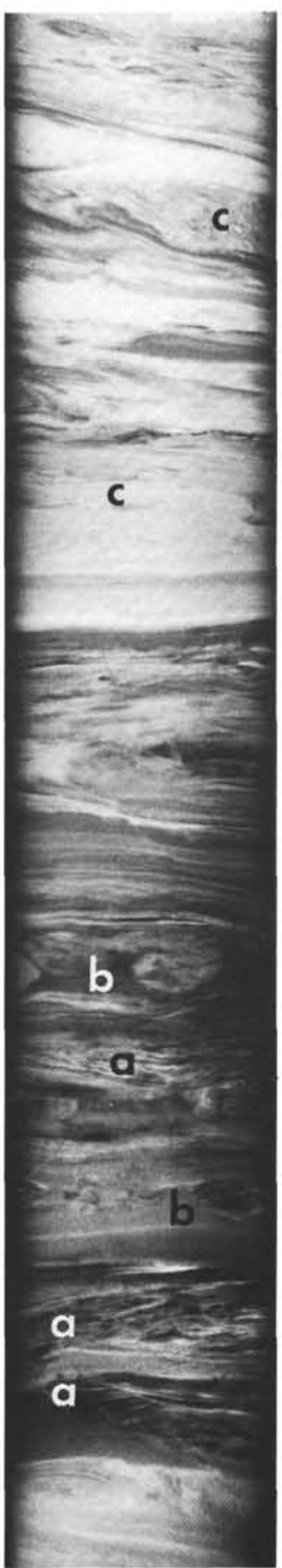

C

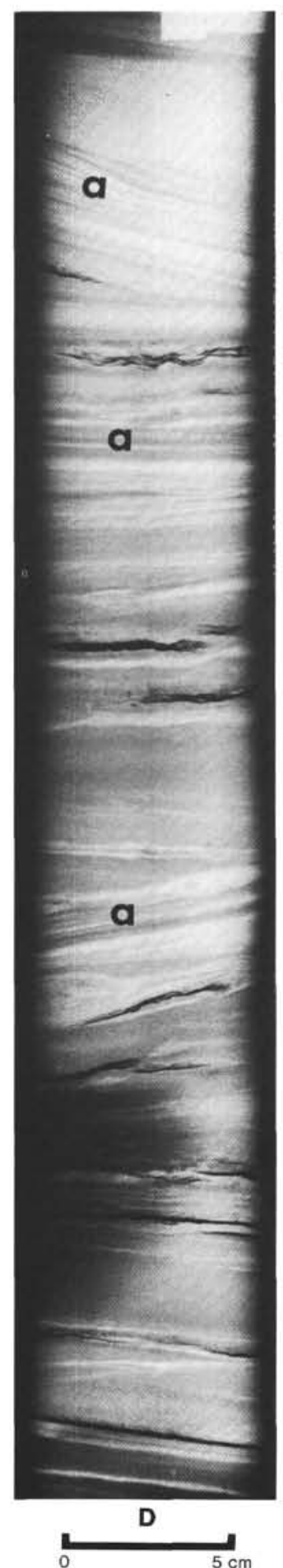

Figure 3. Radiographs of Mississippi Fan cores. A. Sample 617-1-2, 73-103 cm; overbank. B. Sample 617-5-6, 11-41 cm; overbank. C. Sample 617-10-1, 77-107 cm; overbank. D. Sample 617-11-1, 57-87; overbank. 
(c in Figs. 3A, 5A), primarily iron and carbonate-cemented silt nodules, are present in some of the near-surface cores.

One of the characteristic features in all of the overbank cores is the presence of distorted structures, ranging in scale from several meters (tilted and microfractured bedding) to small-scale convoluted laminations (Fig. 3B). These types of bedding disruptions are undoubtedly local and are probably associated with the extremely high sedimentation rates of the overbank deposits. In the coarser grained units (very fine sand and coarse silt), stranded ripples ( $\mathrm{a}$ in Fig. 3C), small load features (b in Fig. 3C), and occasional clay clasts (c in Fig. 3C) are present. Although bioturbation is evident, it is not common and is generally scattered throughout the cores. The sample slabs containing only fine silt and clay display extremely thin graded laminations (a in Fig. 3D), generally grading from fine silt or coarse clay to very fine clay.

The suite of sedimentary structures observed in sediment slabs collected from Sites 617 and 620 indicate that only fine-grained density flows are responsible for sediment deposition in the overbank areas and that coarser grained sediments are confined primarily to the middle fan channel. Traction currents exist, as evidenced by the presence of small-scale and microcross-laminations. Some of the thin graded clay layers contain planktonic and deep-water benthic faunas and therefore represent hemipelagic sedimentation. High sedimentation rates probably induce localized sediment deformation, but this is generally of small scale (a few meters of thickness at most).

\section{SLUMP-MARGINAL FAN DEPOSITS}

Site 616 was drilled on the margin of the youngest fan lobe in a region described in the literature as a massive "slump" (Walker and Massingill, 1970). The upper $96 \mathrm{~m}$ of Hole 616 is composed primarily of clay and thin silt stringers that display a wide range of sedimentary structures (Fig. 4A-D). Although the bedding planes have variable dip angles, ranging from flat-lying to dip angles of $65^{\circ}$, microfractures are generally not abundant. Within the "slump mass," dipping units are often separated by parallel-bedded sequences (Fig. 4A), implying that the material failed as a series of smaller slumps rather than one massive failure. The sediments within the slump mass consist of thin, normally graded laminations (Fig. $4 \mathrm{~A}-\mathrm{C})$. The laminations generally consist of a basal thin silt that grades upward into fine-grained clay ( $\mathrm{a}$ in Fig. 5B). The radiograph in Figure 4D illustrates the base of one of the dipping units and shows that high distortion and fracturing ( $\mathrm{a}$ in Fig. 4D) are present. Although the origin of the slump has not been ascertained, Coleman et al. (1983) described a massive late Pleistocene shelfedge failure off the Mississippi Delta that can be traced seismically down the slope to within a few tens of kilometers of the drill site.

\section{LOWER FAN CHANNEL-OVERBANK DEPOSITS}

In the lower fan, the main channel narrows considerably and displays much less sinuosity. The levees border- ing the channel are subdued, and it is apparent that flow was not as confined in this region as in the middle fan. Site 623 was drilled on the banks of the active channel in a region where seismic reflection profiles and side-scan sonar data indicate the presence of many abandoned channels, suggestive of a shifting sequence of channels through relatively short periods of time. Cores from this site consist of alternating units of channel fill (fining upward sand and silt units) and overbank sediments (alternating fine sands, silts, and clays). The sands are always sharp based (a in Fig. 6A), commonly show minor scouring into underlying clays, and contain abundant scattered woody debris (low absorption inclusions in Fig. 6A). Mica and concentrated layers of woody debris (b in Fig. 6A) are common. Inclusions of rip-up clay clasts are characteristic of the channel units. The larger clay clasts (a in Fig. 6B) are generally angular and show little or no distortion of laminations. Sharp basal scours are normally present on the thicker sand units (b in Fig. 6B). The sand layers within the channel units are commonly separated by very thin clay layers ( $\mathrm{a}$ in Fig. 6D) that display little or no internal structure.

The thin coarser units display three major types of stratification. The first type consists of well-developed microcross-laminations (b in Fig. 6C; Fig. 5C) that grade upward into parallel-laminated silts that often show minor distorted layers (b in Fig. 6C). The microcross-laminations (Fig. 5C) contain abundant mica (high absorption) and transported organics (low absorption) along the bedding planes. The second type is thin sands $(b$ in Fig. 6D) that show little or no internal stratification, display sharp tops and bases, and contain scattered woody debris and redeposited shallow-water benthic microfauna. The third type of stratification consists of finer grained sands that tend to be graded and arranged in numerous thin cycles (c in Fig. 6D; Fig 8A). The sands are thinly parallel, normally graded laminations or display extremely small-scale microcross-laminations (a in Fig. 8A).

In Hole 624, drilled several kilometers away from the channel complex, the overall grain size is considerably finer, laminations are much thinner, and no major sand units were encountered. The fine silts and clays are extremely thinly laminated (Fig. 7A, B), with thicknesses ranging from only a fraction of a millimeter to a few centimeters. The thin, normally graded parallel laminations are characterized by a lack of any basal scouring. Occasionally very thin microcross-laminated fine silt stringers ( $\mathrm{a}$ in Fig. 7A, B) occur. The delicate nature of these thin-graded laminations is illustrated in Figures 7A and 8B. A high percentage of the overbank sediments in the lower fan display this type of bedding. Each unit generally consists of a thinly parallel-laminated or microcross-laminated, sharp-based silt grading upward into low-absorption clays that often show microburrowing at the top. Small-scale contorted bedding, only a few centimeters thick, is also common. Transported organic debris is abundant in the silts and fine sands.

The alternation of coarser channel sands with thinbedded overbank silts and clays in the lower fan indicates that the small channels tend to remain active for a period of time and then switch to alternate lateral posi- 

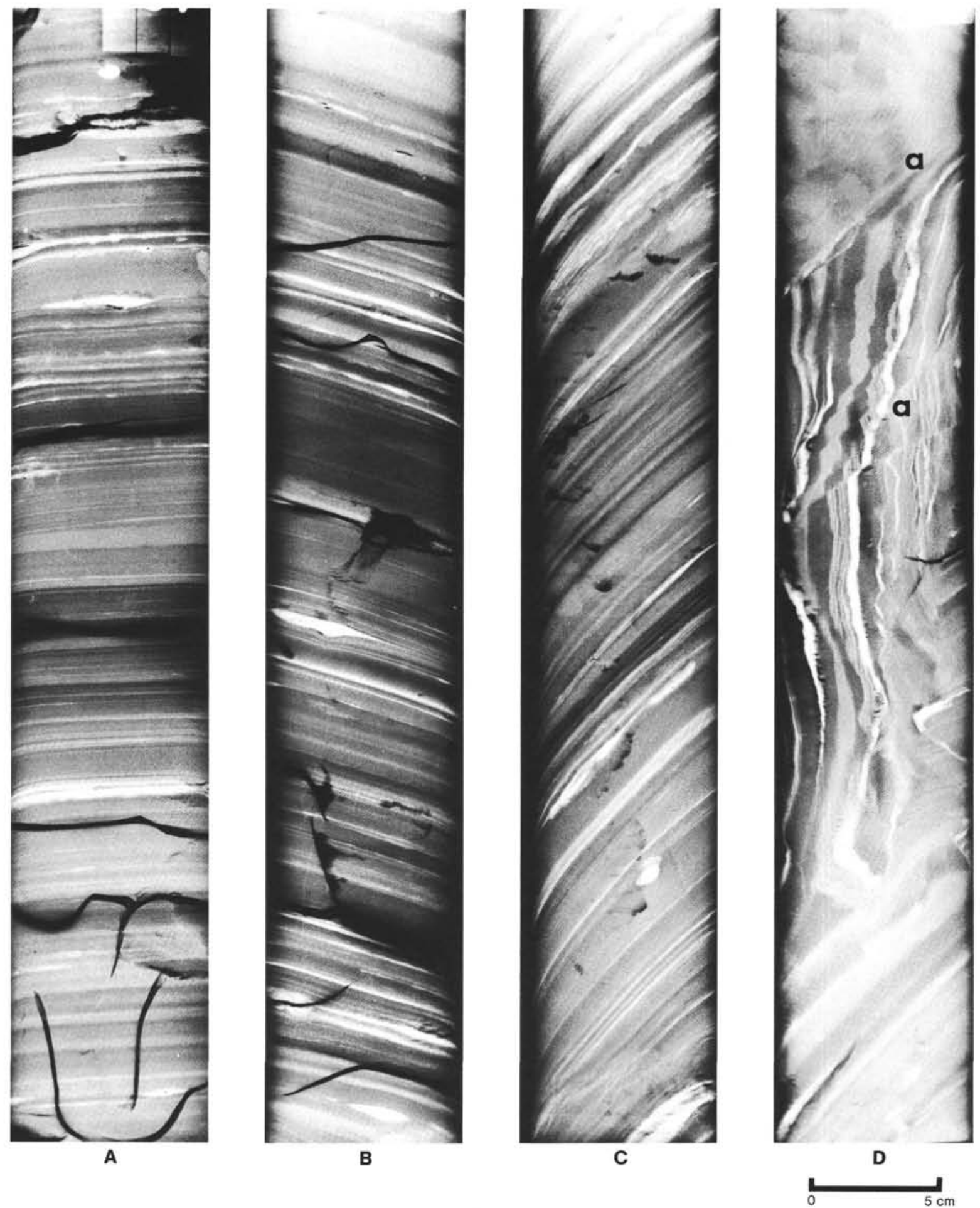

Figure 4. Radiographs of Mississippi Fan cores. A. Sample 616-1-3, 65-95 cm; slump. B. Sample 616-2-3, 72-102 cm; slump. C. Sample 616-4-1, 71-106 cm; slump. D. Sample 616-4-3, 30-60 cm; slump.

tions. The channels, being smaller in size and depth than in the middle fan channel, cannot contain the entire sediment yield associated with the density flows; large amounts escape the channel confines and spread out as overbank deposits that in turn bury the abandoned channels. Although the channels are not extremely large, currents moving down them are capable of carrying rela- tively coarse sediment and of scouring, as evidenced by the abundance of rip-up clasts found within the channel sequences.

\section{LOWER FAN CHANNEL-MOUTH SHEET SANDS}

Two sites (615 and 614) near the terminus of the channel in the lower fan were visited. Although the channel 


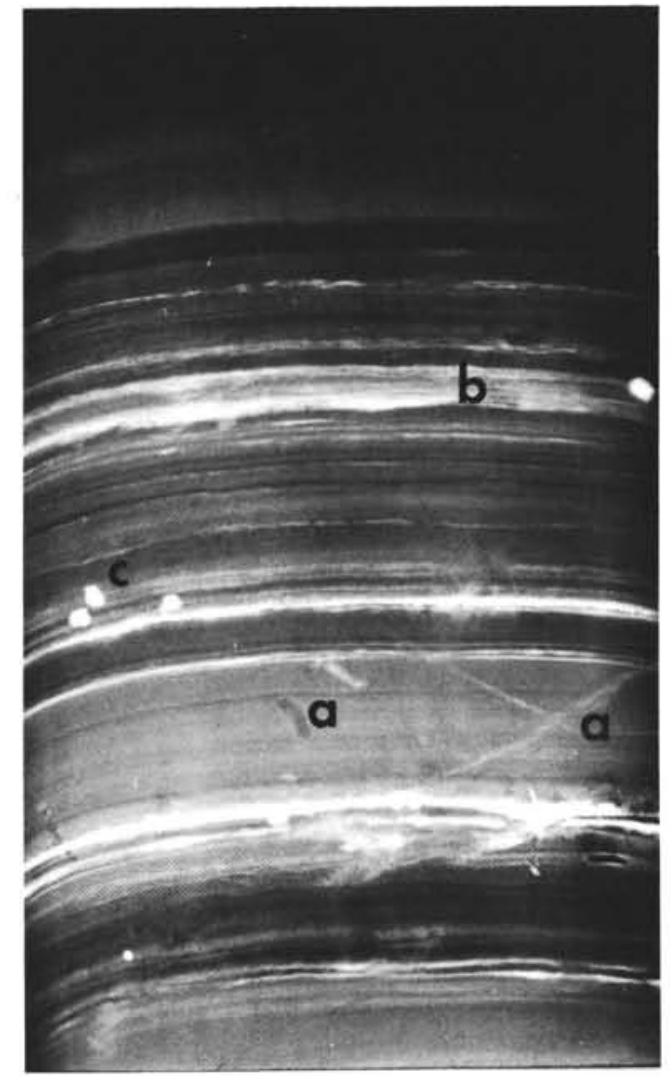

A

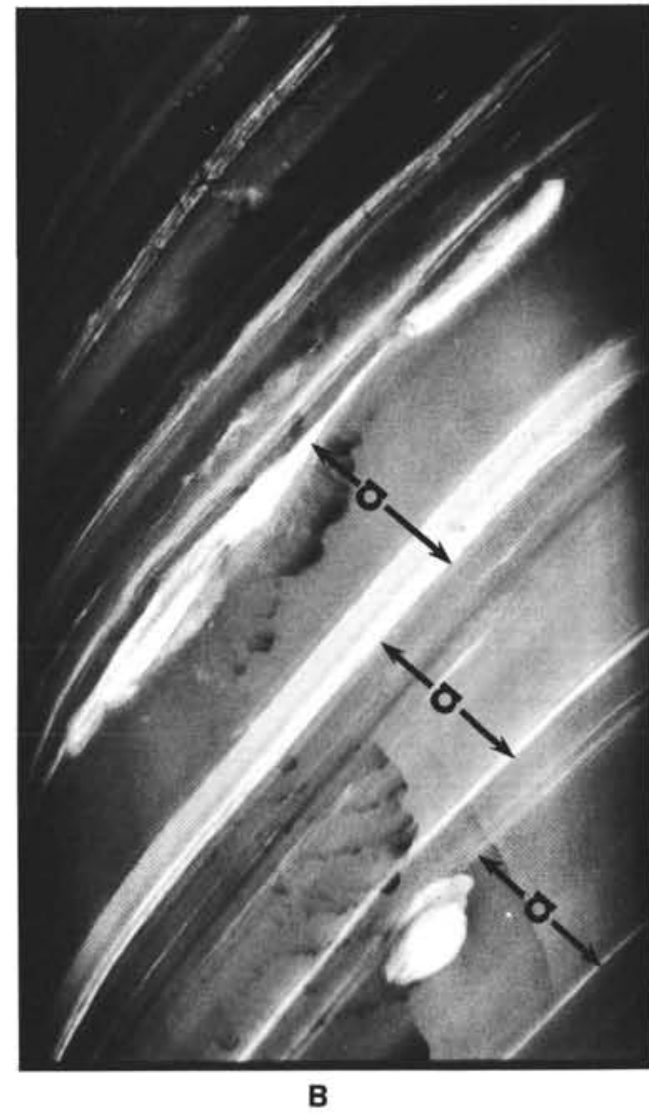

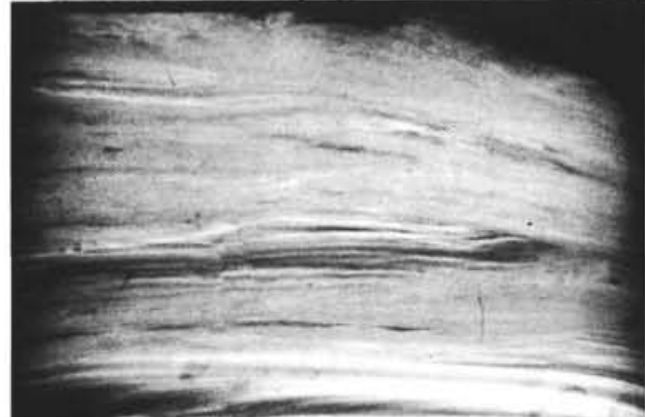
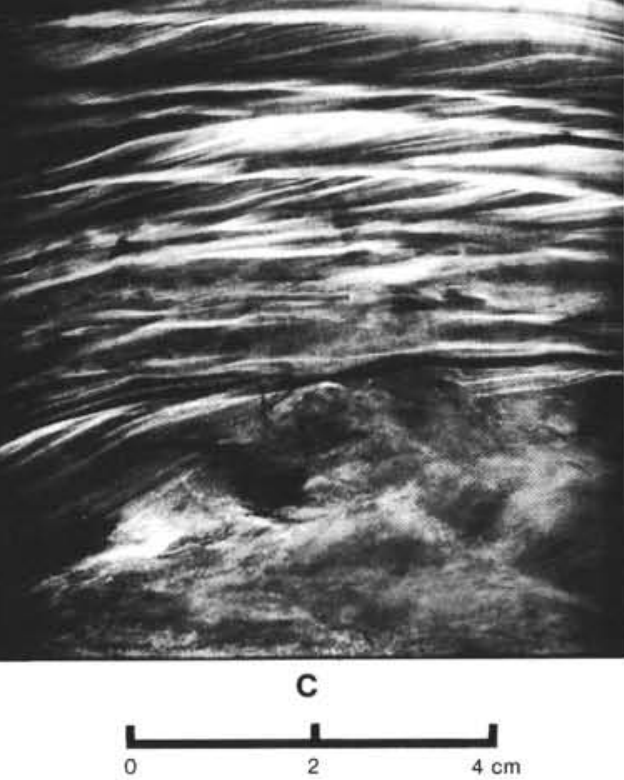

$4 \mathrm{~cm}$

Figure 5. Radiographs of Mississippi Fan cores. A. Sample 617-1-2, 84-95 cm; overbank. B. Sample 616-4-1, 85-96 cm; slump. C. Sample 623-9-4, 17-28 cm; channel. 


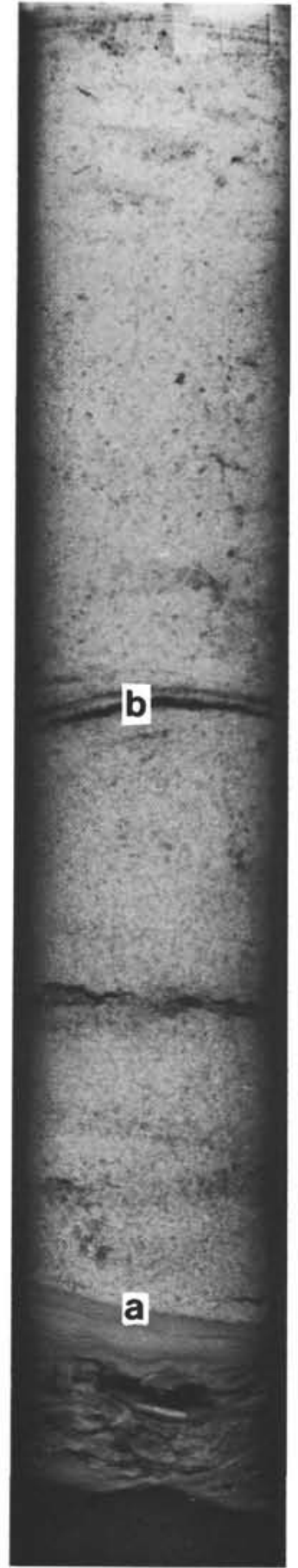

A

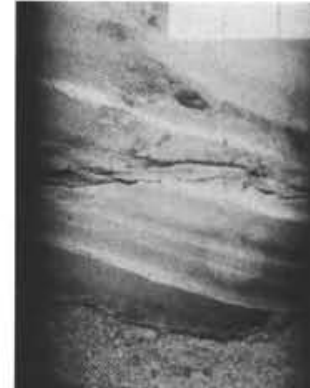

a

a

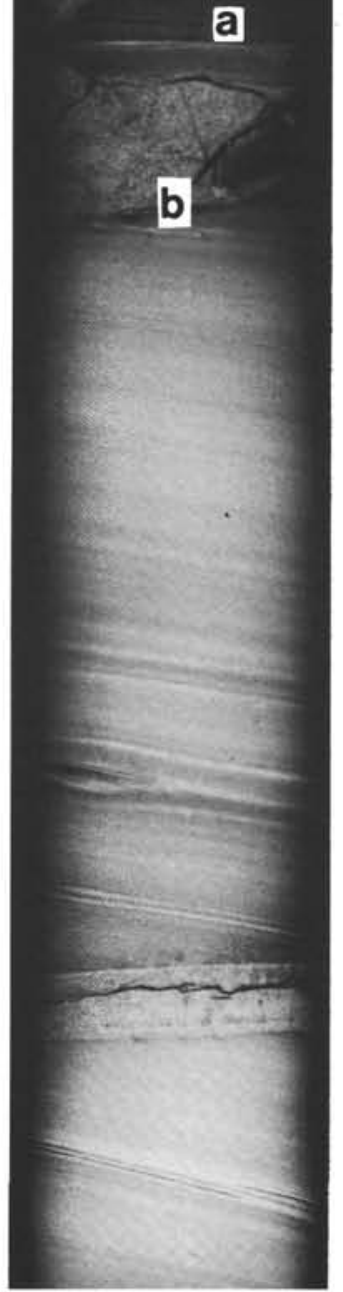

B

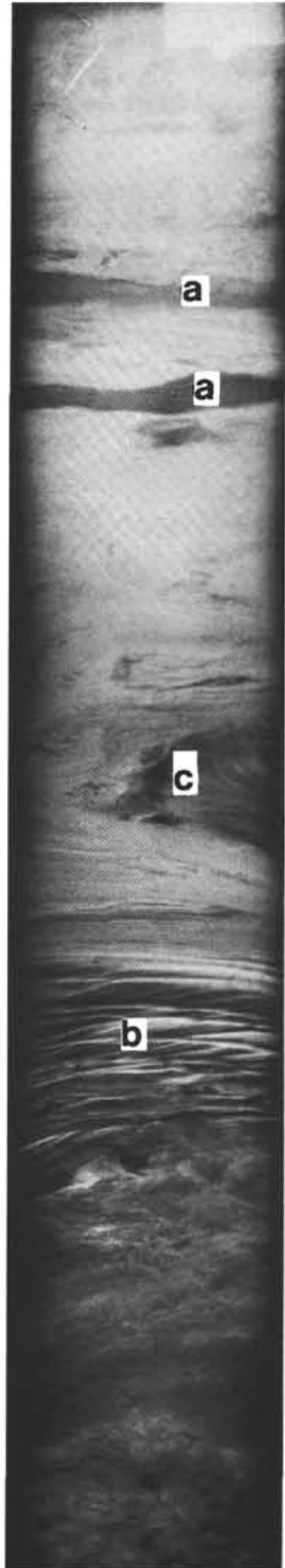

C
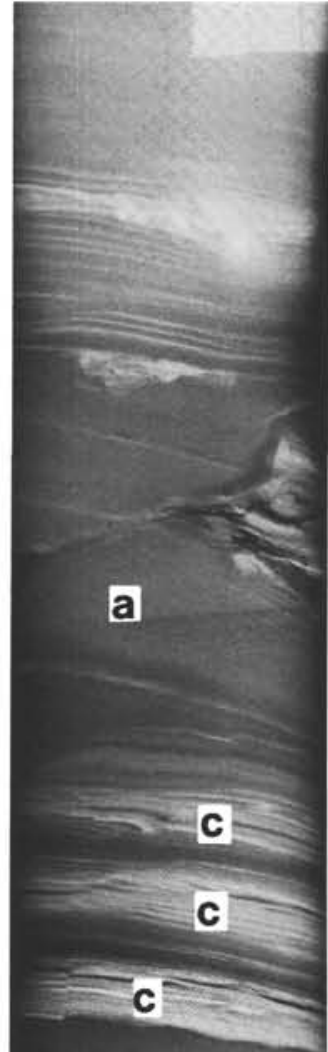

a

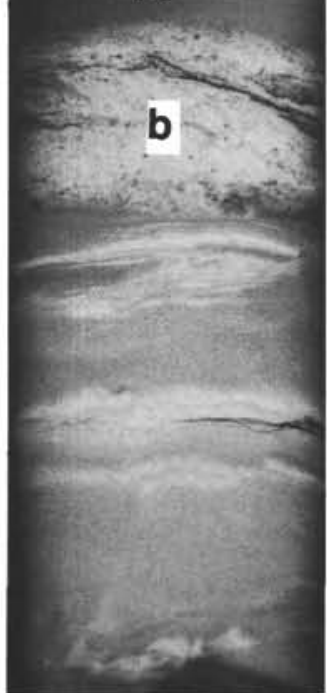

D

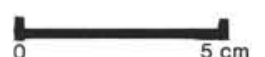

Figure 6. Radiographs of Mississippi Fan cores. A. Sample 623-8-2, 21-51 cm; channel. B. Sample 623-14-2, 2-32 cm; channel. C, Sample 623-9-4, 2-32 cm; channel. D. Sample 623-6-4, 87-117 cm; channel.

displays very small bifurcations in the most distal part of the fan, they are barely discernible on the side-scan sonar images. This area represents the point at which sediments are no longer confined to the channel but are free to spread laterally. The sediments in the core contain a considerable amount of sand; of the two fan lobes of upper Wisconsin age cored at Site 615, the older lobe contains $65 \%$ net sand and the younger lobe contains
$41 \%$ net sand (Site 615 chapter, this volume). The coarser units are dominantly composed of medium- to finegrained massive sands containing thin silt and clay beds. The sands are generally sublitharenites composed of quartz, with subordinate feldspars, rock fragments, micas, and heavy minerals. They contain minor amounts of reworked foraminifer tests, glauconite, shell debris, and transported organic debris. Contacts are sharp (a in 


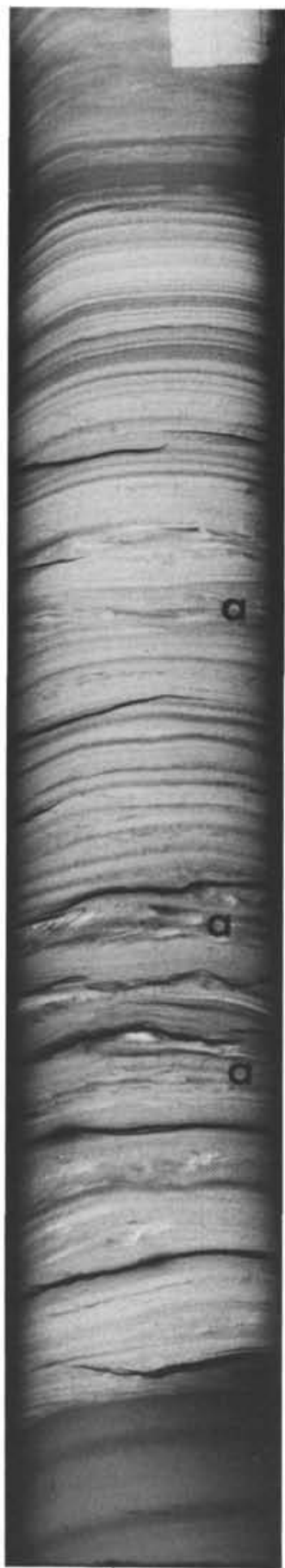

A

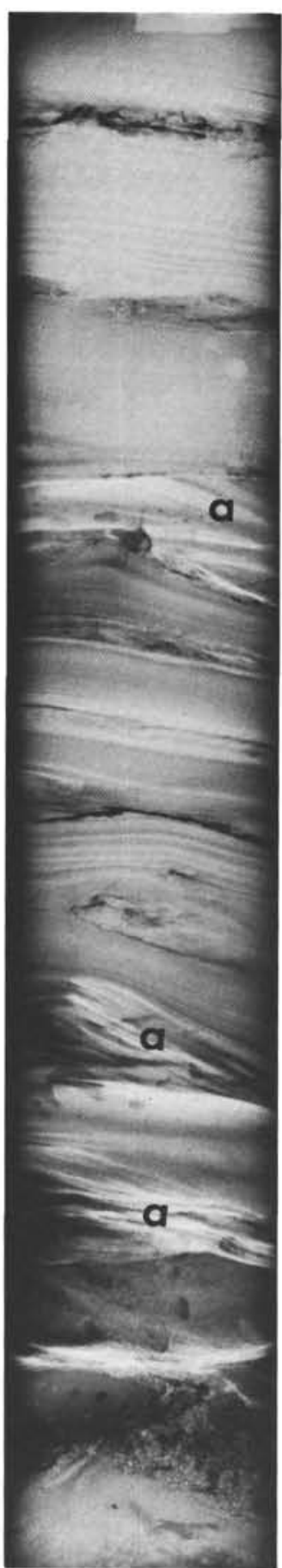

B

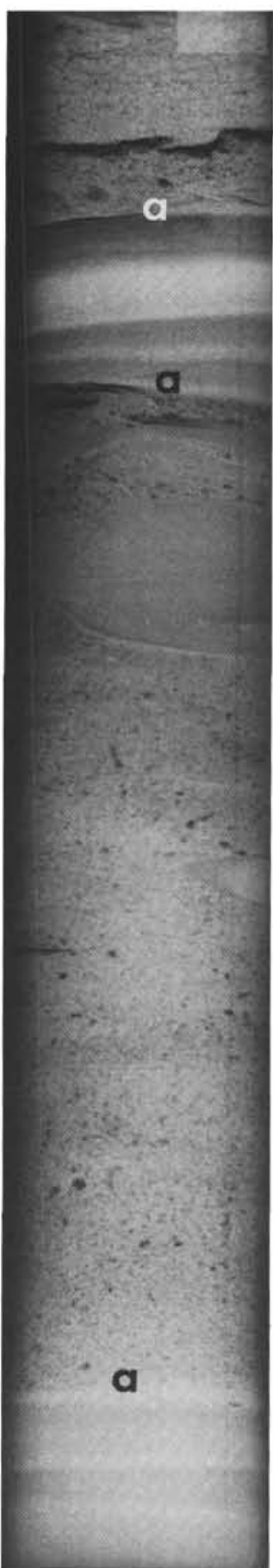

C

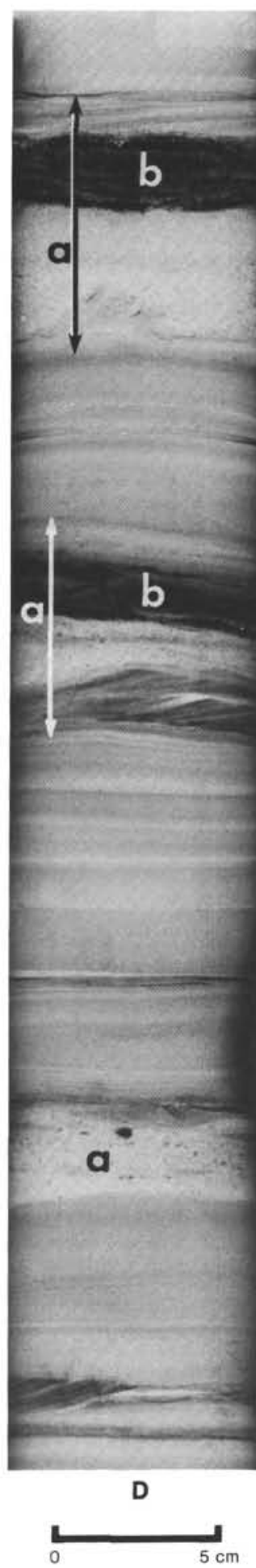

Figure 7. Radiographs of Mississippi Fan cores. A. Sample 624-7-3, 27-57 cm; overbank; B. Sample 624-20-1, 62-92 cm; overbank. C. Sample 615-22-2, 56-85 cm; channel mouth. D. Sample 615-23-2, 8-38 cm; channel mouth.

Fig. 7C) and often display microscouring at the base. Except for clay clasts 1 to $5 \mathrm{~cm}$ in size (Fig. 7C) and well-defined horizons of transported organic debris, these coarse units display little internal structure. The interbedded fine sand, silt, and clay units are generally graded and occur in repetitive cycles a few millimeters to tens of centimeters in thickness ( $a$ in Fig. 7D). The finer grained sands generally show sharp basal contacts ( $a$ in
Fig. $8 \mathrm{C}$ ) and cross-laminations at the base (b in Fig. 8C). Organic debris is often scattered throughout the sand layers (c in Fig. 8C) or concentrated into thin units (d in Fig. 8C; b in Fig. 7D) a few centimeters thick. In some instances, the sands display abundant multidirectional scour surfaces (a in Fig. 9A).

The finer grained silts and clays that separate the sands are characterized by an abundance of thin, normally 


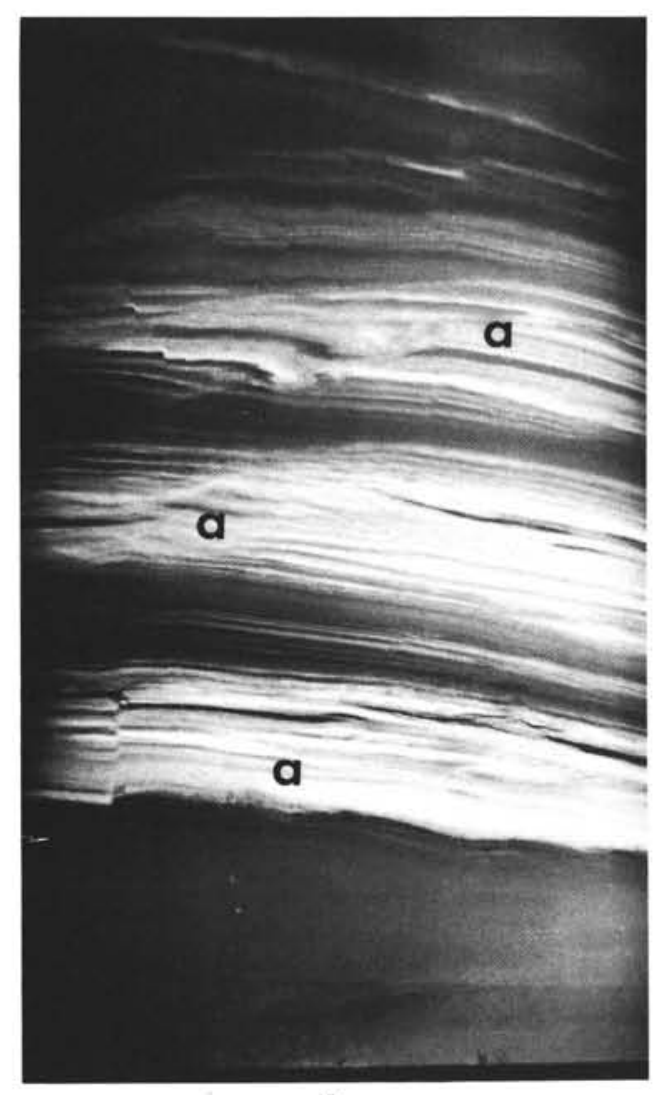

A
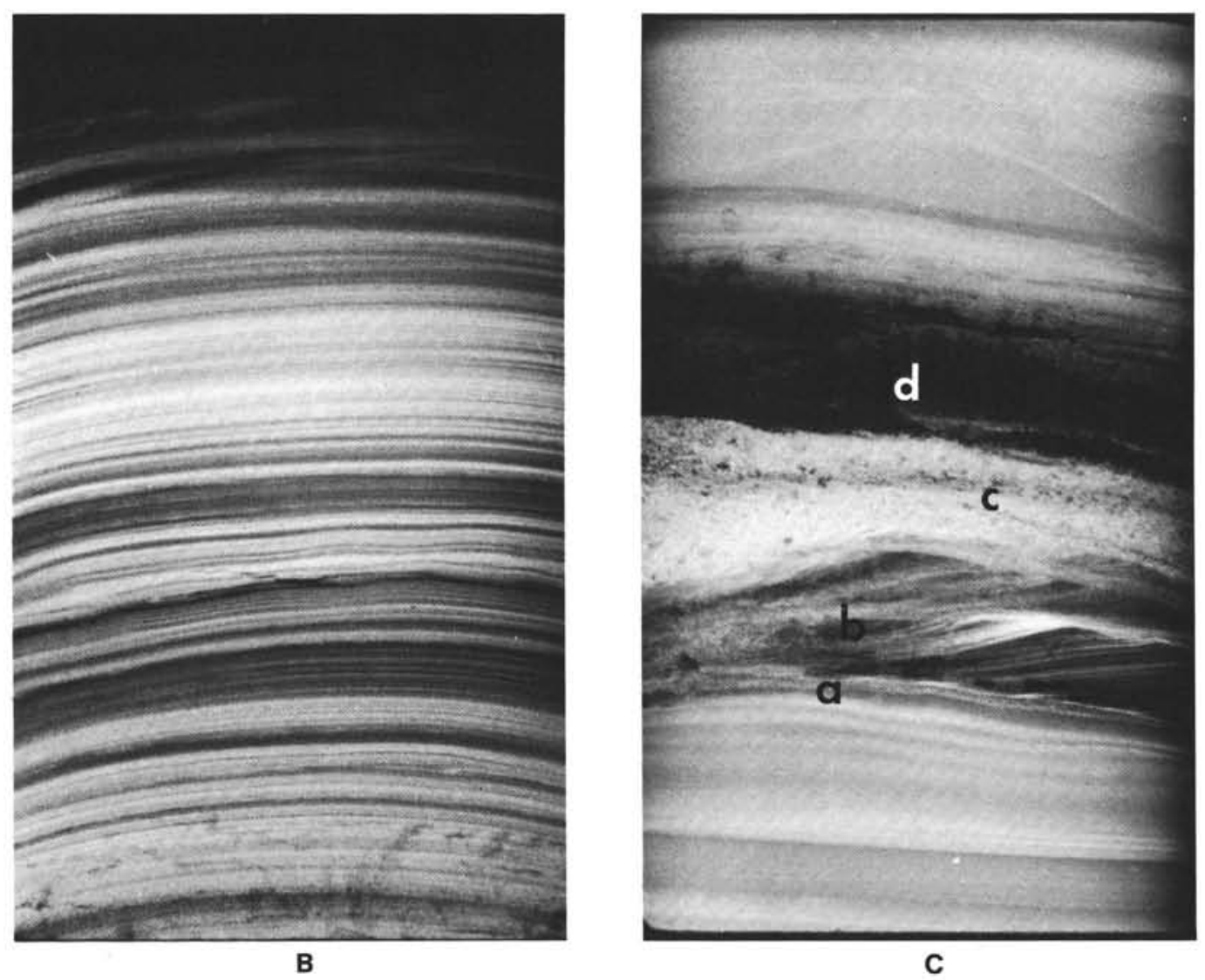

C

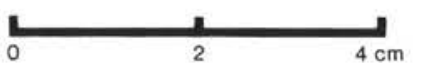

Figure 8. Radiographs of Mississippi Fan cores. A. Sample 623-6-4, 97-108 cm; channel. B. Sample 624-7-3, 29-38 cm; overbank. C. Sample 615-23-2, 18-27 cm; channel mouth. 


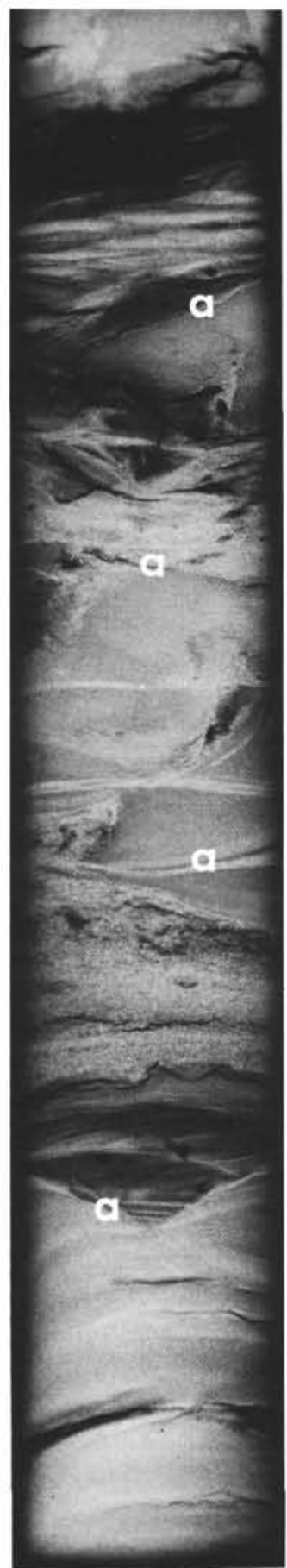

A

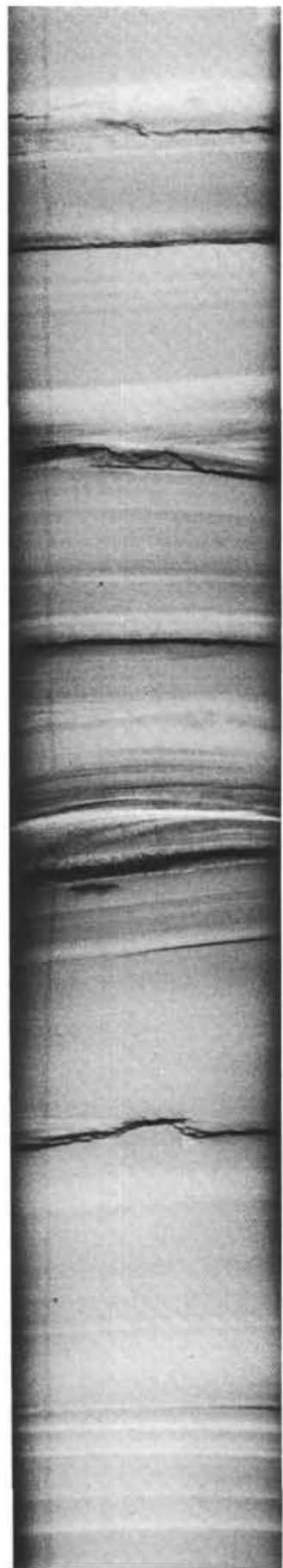

B

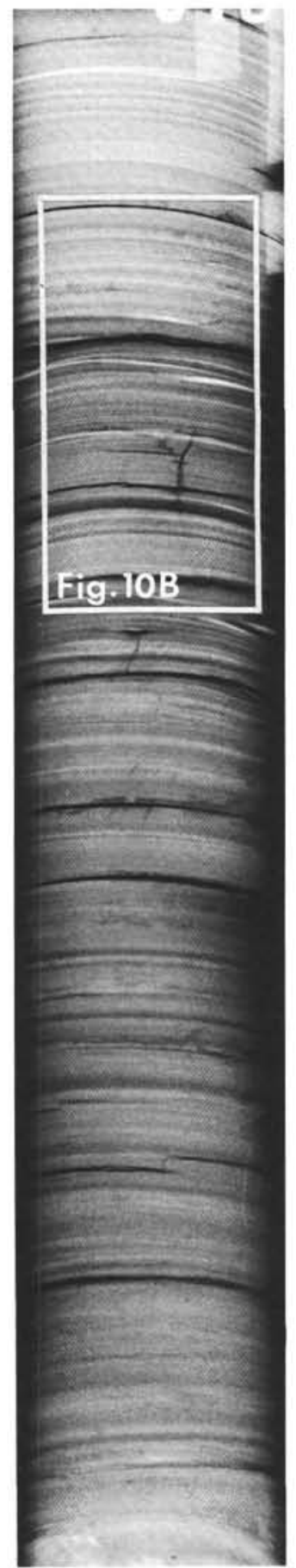

C

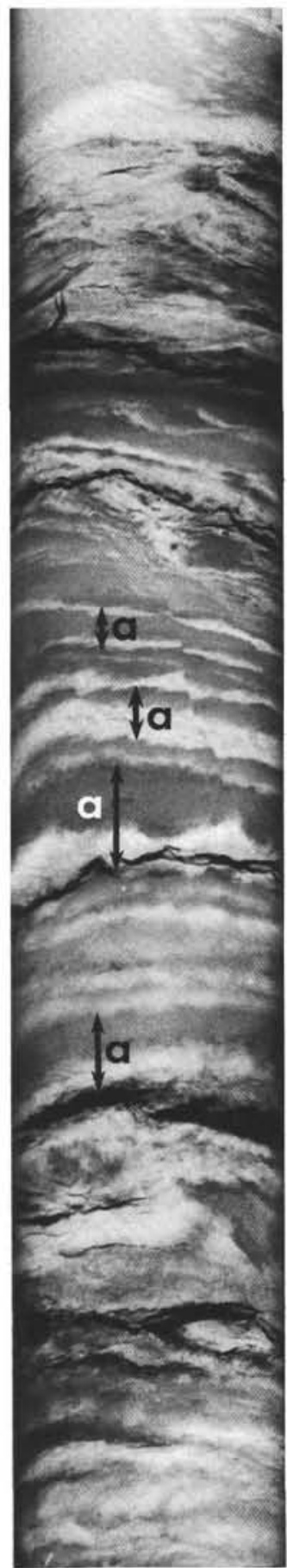

D

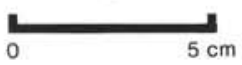

Figure 9. Radiographs of Mississippi Fan cores. A. Sample 614A-11-2, 65-95 cm; channel mouth. B. Sample 614A-8-2, 59-89 cm; channel mouth. C. Sample 615-11-3, 95-125 cm; channel mouth. D. Sample 615-5-6, 43-73 cm; channel mouth.

graded laminations (Fig. 9B, C). Graded laminations that are thicker than a centimeter or so generally tend to contain little silt and are composed primarily of clay. Figure 10A illustrates an enlargement of this type of lamination. The sharp, nonscoured base is often composed of a 1- to 2-mm-thick silt that grades upward into a homogeneous clay 1 to $3 \mathrm{~cm}$ thick. Internal stratifica- tion is commonly lacking in the clays. Scattered planktonic and redeposited shallow-water benthic microfauna are often found in these units. More commonly, the finer grained sediments separating the sands display very thin graded laminations (a few millimeters thick) such as those shown in Figure 9C. These well-developed graded laminae occur as repetitive cycles, often numbering 


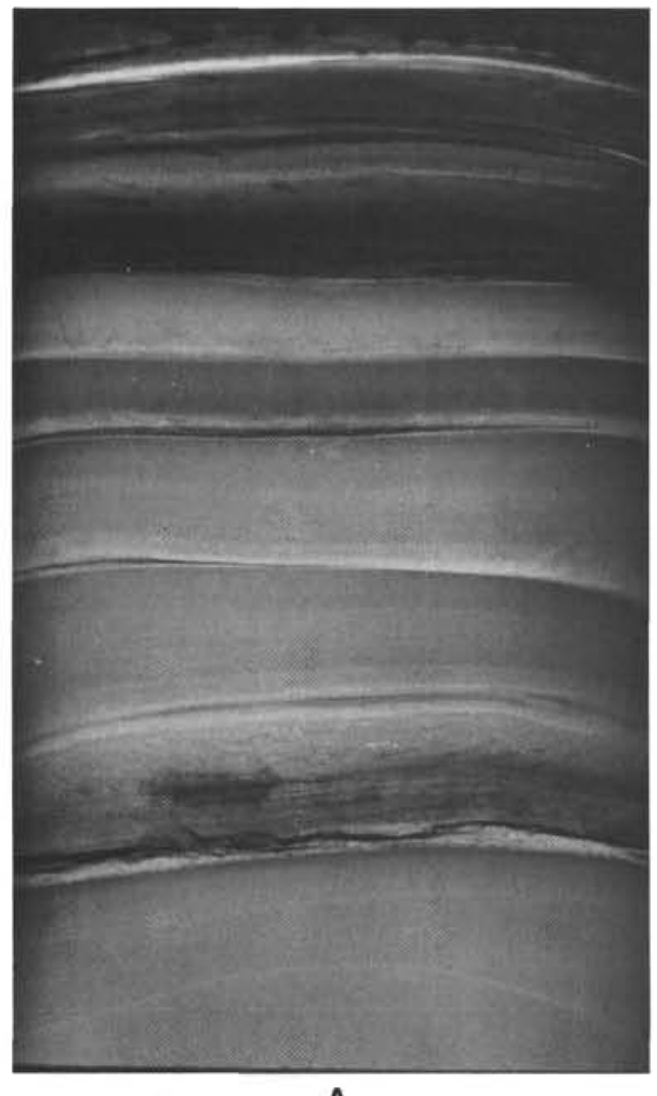

A

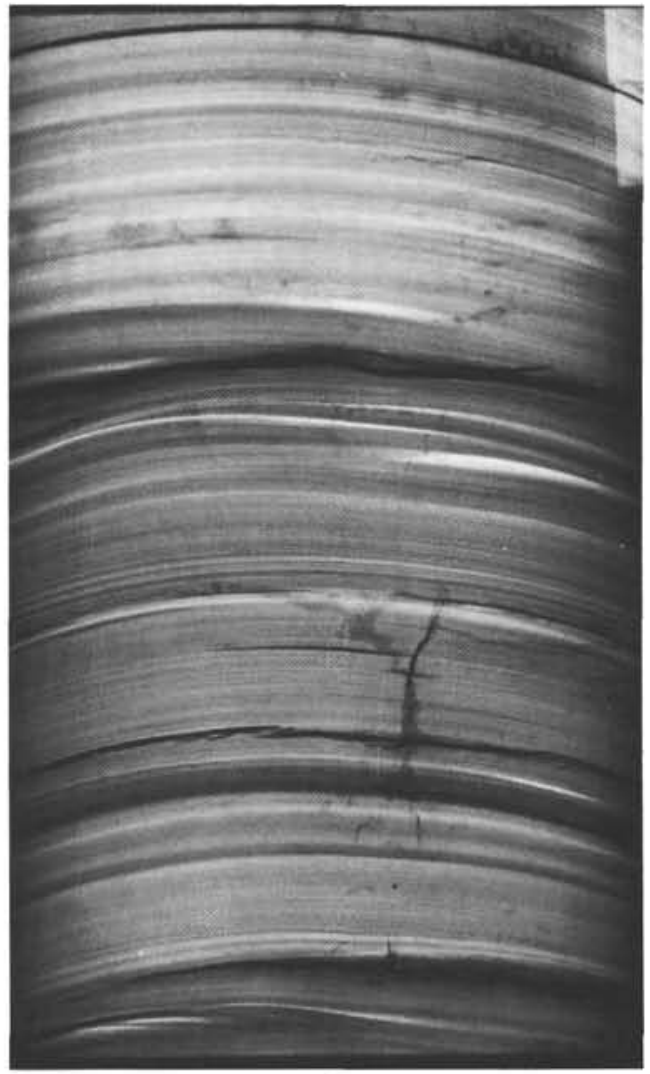

B

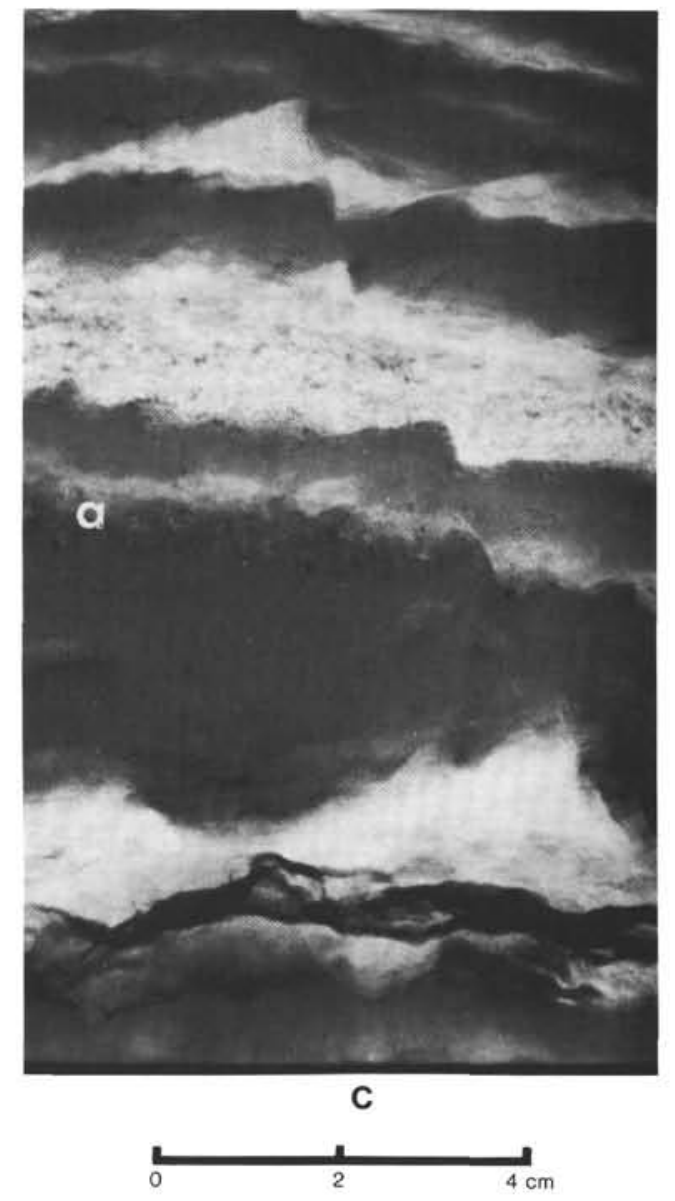

Figure 10. Radiographs of Mississippi Fan cores. A. Sample 615-19-1, 22-33 cm; channel mouth; B. Sample 615-11-3, 98-106 cm; channel mouth. C. Sample 615-5-6, 55-62 cm; channel mouth. 
15 to 20 laminations per centimeter of core. Figure 10B illustrates the delicate nature of this type of lamination; it is probably the most common type of structure in the more distal parts of the fan.

One of the more common attributes of the thinly graded units in these cores, as well as many of those in the overbank settings, is the presence of a thin concentration of microfauna, mainly foraminifers, at the top of the fine-grained graded units. Figure 9D illustrates a core from Site 615 showing the thickness variation in the repetitive graded units (a in Fig. 9D); some microfracturing is present in the core. In Figure 10C, an enlargement of a part of Figure 9D, the concentration of foraminifers (a in Fig. 10C) can be seen at the top of the low-absorption clay. The presence of this foraminifer concentration, containing primarily planktonic and some deep-water benthic species, indicates a break in the rapid deposition of the thin-graded units that are normally barren of microfauna. The thickness of the intervals between these foraminifer concentrations varies but commonly is less than $0.5 \mathrm{~m}$.

\section{CONCLUSIONS}

The X-ray radiography study of microstructures in the cores from the Mississippi Fan provides considerable information on some of the processes that were active during deposition of the fan lobes. The most characteristic feature is the abundance of graded units of variable thickness and grain size. Some of these units consist of sand grading to silt, while others are composed of silt grading to very fine-grained clay. Based on average sedimentation rates computed from faunal boundaries (site chapters, this volume), it is highly probable that more than one such fine-grained graded unit, and possibly as many as five or six, were deposited per year. Deposition of the fine clays suggests an accumulation period of at least hours or days before introduction of the sediment forming the overlying graded unit.

The presence of a foraminifer concentration capping only selected units (ranging from every third to every tenth unit) supports the concept that the processes responsible for delivering shelf-derived sediment to the fan operate an average of several times per year, but are geologically continuous over relatively long periods of time (the late Wisconsin glacial stages). The coarser grained graded beds, which lack burrows and foraminifers, might be the result of pulsations in a turbidity current, with a set of such beds being deposited in a very short time. Deposition rates were extremely high, as little evidence of burrowing organisms was observed in the cores. The lack of extensive scouring at the base of the sands supports the concept of rapid suspension settling rather than highly erosive density or gravity flows. Traction currents, however, were operative, as many of the thin basal sand and silt units display microcross-stratification.

In the middle fan, the coarser debris carried by the density flows is confined to the channel, and only the finer grained sediments escape the channel to be deposited as overbank sediments. In the lower fan, the channels decrease in size, tend to switch position often, and result in vertically stacked alternating channel sands and overbank deposits. Generally, the overbank deposits in the lower fan contain more microfauna and cross-laminated silts and fine sands than those in the middle fan. Near the distal ends of the channel, density flows are no longer confined by channel banks and are capable of spreading laterally, resulting in alternating sequences of rather thick sands separated by thinly laminated silts and clays that display extremely delicate graded laminations. A wide range of grain sizes, including high volumes of reworked organic debris and mica, were transported long distances from their source and incorporated into the coarser sediments. Many of the minor structure associations cannot yet be explained, and considerably more work on the Mississippi Fan cores, as well as cores from other types of modern fans, is needed to determine the details of the depositional processes active in deep-sea fans.

\section{REFERENCES}

Coleman, J. M., Prior, D. B., and Lindsay, J. F., 1983. Deltaic influences on shelf edge instability processes. In Stanley, D. J., and Moore, G. T. (Eds.), The Shelf Break, Critical Interface on Continental Margins. Soc. Econ. Paleontol. Mineral. Spec. Publ., 33: 161-199.

Walker, J. R., and Massingill, J. V., 1970. Slump features on the Mississippi fan, northeastern Gulf of Mexico. Geol. Soc. Am. Bull., 81:3101-3108.

Date of Initial Receipt: 11 December 1984

Date of Acceptance: 5 March 1985 